\title{
PENGARUH PEMBENTUK FILM PVA PADA SEDIAAN MASKER GEL PEEL-OFF EKSTRAK ETANOL BAWANG DAYAK (Eleutherina palmifolia (L.) Merr) TERHADAP AKTIVITAS ANTIBAKTERI Staphylococcus aureus PENYEBAB JERAWAT
}

Akademi Farmasi Yarsi Pontianak

\author{
Husnani $^{1)}$, Fitri Sri Rizki ${ }^{1)}$
}

Jl. Panglima A'im no 2 Pontianak

Email: husnani.apoteker@gmail.com

\section{INTISARI}

Bawang dayak (Eleutherine palmifolia) merupakan salah satu tanaman yang yang dapat menghambat bakteri Staphylococcus aureus penyebab jerawat. Penelitian ini bertujuan untuk mengetahui pengaruh polyvinyl alkohol pada sediaan masker gel peel-off dari ekstrak etanol bawang dayak terhadap aktivitas antibakteri Staphylococcus aureus penyebab jerawat. Ekstraksi menggunakan metode maserasi dengan pelarut etanol 96\%. Konsentrasi ekstrak bawang dayak dibuat sebesar 5\%, 7,5\%, dan 10\% sedangkan pada formula masker gel peel-off dari ekstrak bawang dayak dibuat juga dengan variasi konsentrasi ekstrak yaitu 5\%, 7,5\%, dan 10\% dengan basis Polyvinyl Alkohol (PVA). Aktivitas antibakteri dilakukan dengan metode cakram disk. Pada pengujian daya hambat ekstrak bawang dayak pada konsentrasi $5 \%$ menghasilkan zona bening sebesar 15,5 mm, konsentrasi 7,5\% dan 10\% menghasilkan diameter zona bening yang sama sebesar 17,1 mm. Pada sediaan masker gel peel-off pada formulasi I didapatkan diameter zona beningnya sebesar 8,7 $\mathrm{mm}$, formulasi II diameter zona beningnya sebesar $12,2 \mathrm{~mm}$, dan formula III diameter zona beningnya sebesar 15,3 mm. Hasil penelitian ini menunjukkan bahwa pada ekstrak bawang dayak memiliki daya hambat yang lebih besar dibandingkan dengan sediaan masker gel peel-off ekstrak bawang dayak. Dapat disimpulkan bahwa PVA yang ada pada sediaan mempengaruhi besarnya daya hambat terhadap bakteri pembentukan jerawat yaitu Staphylococcus aureus.

Kata Kunci : Ekstrak bawang dayak, Staphylococcus aureus, cakram disk, uji daya hambat antibakteri, bakteri penyebab jerawat, masker gel peel-off.

\begin{abstract}
Dayak Onion (Eleutherine palmifolia) is one of the plants that can inhibit Staphylococcus aureus bacteria that causes acne. This study aims to determine the effect of polyvinyl alcohol on peel-off gel mask preparations from onion dayak ethanol extract on the antibacterial activity of Staphylococcus aureus that causes acne. Extraction using maceration method with $96 \%$ ethanol. The concentration of dayak onion extract was made at $5 \%, 7.5 \%$, and $10 \%$ and the peel-off gel mask formula from dayak onion extract with variations in extract concentration were 5\%, 7.5\%, and $10 \%$ based on Polyvinyl Alcohol (PVA). Antibacterial activity is carried out using the disk disc method. In testing the inhibition of dayak onion extract at a concentration of $5 \%$ resulted in a clear zone of $15.5 \mathrm{~mm}$, a concentration of $7.5 \%$ and $10 \%$ producing the same clear zone diameter of $17.1 \mathrm{~mm}$. The peel-off gel mask in formulation I obtained a clear zone diameter of $8.7 \mathrm{~mm}$, formulation II the diameter of the clear zone was $12.2 \mathrm{~mm}$, and formula III the diameter of the clear zone was $15.3 \mathrm{~mm}$. The results of this study indicate that on dayak onion extract has a greater inhibitory power compared to the dayak onion extract peel-off gel mask preparation. It can be concluded that the PVA in the preparation affects the amount of inhibitory power on the bacteria forming acne, namely Staphylococcus aureus.
\end{abstract}

Keywords: Dayak onion extract, Staphylococcus aureus, disk discs, antibacterial inhibitory test, acne-causing bacteria, peel-off gel mask.

Corresponding author:

Husnani 
Akademi Farmasi Yarsi Pontianak

Jl. Panglima A'im, No 02, Pontianak

Email: husnani.apoteker@gmail.com

\section{PENDAHULUAN}

Penyakit kulit yang kebanyakan mencemaskan para remaja maupun orang dewasa adalah jerawat. Jerawat atau acne vulgaris merupakan berupa peradangan menahun pada lapisan folikel pilosebaseus yang disertai penyumbatan dan penimbunan bahan keratin yang dipicu oleh bakteri Staphylococcus aureus (BPOM RI, 2009). Jerawat bisa diobati secara oral maupun topikal, biasanya diberikan obat antibiotik dan berasal dari bahan kimia. Obat-obatan tersebut kebanyakan memiliki efek samping seperti resistensi dan iritasi kulit. Oleh karena itu dilakukan penelitian antibakteri yang berasal dari bahan alam yang diketahui lebih aman dibanding bahan kimia.

Mierza (2011) melaporkan bahwa ekstrak bawang dayak (Eleutherine palmifolia) dengan pelarut 80\% mempunyai efek antibakteri terhadap Staphylococcus aureus, didapatkan hasil bahwa semakin tinggi konsentrasi ekstrak bawang dayak maka semakin besar rata-rata zona hambat yang dihasilkan, dalam umbi bawang dayak terkandung senyawa fitokimia mempunyai kandungan golongan senyawa alkaloid, flavonoid, saponin, tannin, glikosid, dan triterpenoid yang mana senyawa-senyawa tersebut diduga memiliki efek antibakteri. Alkaloid, antrakuinon, tannin, dan flavonoid memiliki khasiat sebagai antibakteri pada Staphylococcus aureus.

Menurut Firdaus (2014) membuktikan bahwa ekstrak bawang dayak (Eleutherine palmifolia) dengan pelarut etanol 96\% dapat menghambat pertumbuhan bakteri Staphylococcus aureus dan hasilnya bahwa ekstrak bawang dayak dengan konsentrasi $40 \mathrm{mg} / \mathrm{ml}$ memiliki aktivitas antibakteri yang paling baik dibandingkan dengan konsentrasi $10 \mathrm{mg} / \mathrm{ml}$ dan $20 \mathrm{mg} / \mathrm{ml}$ meskipun termasuk dalam klasifikasi daya hambat lemah. Kalidass (2013) meneliti efek ekstrak bawang dayak (Eleutherine palmifolia) dengan menggunakan pelarut etanol terhadap bakteri MRSA (MethicillinResistant Staphylococcus Aureus) dengan variasi konsentrasi 50 mg/ml, 75 mg/ml dan 100 mg/ml. Dari hasil penelitian tersebut dapat disimpulkan bahwa ekstrak bawang dayak efektif dalam menghambat bakteri Staphylococcus aureus dan semakin tinggi konsentrasi maka zona hambat yang dihasilkan akan semakin besar.

Masker gel peel-off termasuk salah satu masker yang praktis, karena setelah kering masker tersebut dapat langsung diangkat tanpa perlu dibilas. Salah satu basis yang digunakan pada sediaan ini adalah PVA. Salah satu keunggulan PVA diantaranya dapat membuat gel yang dapat mengering secara cepat. Selain itu film yang terbentuk sangat kuat dan plastis sehingga memberikan kontak yang baik antara obat dan kulit (Rowe et al, 2009).

Berdasarkan uraian diatas, maka perlu dilakukan suatu pengujian secara ilmiah untuk memperoleh data yang dapat dipergunakan untuk mengetahui pengaruh pembentuk film PVA dalam sediaan masker gel peel- off ekstrak bawang dayak (Eleutherine palmifolia) terhadap pertumbuhan bakteri pembentukan jerawat Stapyhlococcus aureus.

\section{METODOLOGI PENELITIAN \\ Waktu dan Tempat Penelitian}

Penelitian ini adalah jenis penelitian eksperimental laboratorium. Penelitian ini dilakukan pada bulan April - Juni 2018 bertempat di Laboratorium Mikrobiologi Akademi Farmasi Yarsi Pontianak dan di Laboratorium Politeknik Negeri Pontianak.

\section{Alat dan Bahan}

Peralatan yang digunakan dalam penelitian ini adalah pisau, talenan, oven merk memmert, aluminium foil, timbangan analitik, blender, ayakan mesh 65, bejana kaca, batang pengaduk, gelas ukur, kertas saring whatman no.42, corong, gelas kimia merk pyrex, rotary evaporator, waterbath, pot gel, hot plate, laminar airflow, inkubator, api bunsen, mistar, cawan petri, kaca transparan, $\mathrm{pH}$ meter universal, autoklaf, erlenmeyer merk pyrex, tabung reaksi, sentrifugator, kain flanel, dry cabinet, pencadang logam. Bahan yang digunakan dalam penelitian ini adalah ekstrak Bawang Dayak, etanol $96 \%$ (teknis), polivinil alkohol (PVA), hidroksipropil metilselulosa (HPMC), propilenglikol, trietanolamin (TEA), nipagin, nipasol, sediaan dipasaran sebagai pembanding, Nutrient Agar (NA), bakteri Staphylococcus aureus, $\mathrm{NaCl}$ 0,9\%. 


\section{Pengolahan Sampel}

Bawang dayak diambil dari Rasau jaya sebanyak $20 \mathrm{~kg}$. Bawang dayak dibersihkan dari daunnya, dicuci dengan air mengalir untuk melepaskan kotoran-kotoran yang menempel pada bawang dayak, dirajang tipis dan dikeringkan di dalam oven pada suhu $60^{\circ} \mathrm{C}$. Bawang dayak yang telah kering diserbukkan menggunakan blender selanjutnya dilakukan proses ekstraksi, dalam penelitian ini dilakukan ekstraksi dengan menggunakan metode maserasi. Simplisia serbuk bawang dayak dimasukkan kedalam bejana maserasi, kemudian ditambahkan pelarut etanol $96 \%$ hingga serbuk terendam semua dan sambil sesekali diaduk. Proses ini dilakukan 3 x 24 jam dimana dilakukan pergantian pelarut tiap 1 x 24 jam. Hasil maserasi disaring dengan kain flannel digabungkan maserat dan dipekatkan menggunakan Rotary Evaporator sampai mendapatkan ekstrak kental.

Tabel I. Formula Sediaan Masker Peel-off ekstrak bawang dayak

\begin{tabular}{|c|c|c|c|c|c|}
\hline \multirow{2}{*}{ BAHAN } & \multicolumn{3}{|c|}{ FORMULA } & \multirow{2}{*}{ RANGE } & \multirow{2}{*}{ FUNGSI } \\
\hline & F1 \% & F2\% & F3\% & & \\
\hline Ekstrak Bawang Dayak & 5 & 7,5 & 10 & - & Zat Aktif \\
\hline PVA & 15 & 15 & 15 & 7 & Pembentuk Lapisan film \\
\hline HPMC & 1 & 1 & 1 & $2-4$ & Pembentuk Gel \\
\hline Propilenglikol & 12 & 12 & 12 & $\approx 15$ & Humektan \\
\hline Metil Paraben & 0,02 & 0,02 & 0,02 & $0.02-0.3$ & Pengawet \\
\hline Aquadest ad & 100 & 100 & 100 & - & Pelarut \\
\hline
\end{tabular}

\section{Cara Pembuatan Masker Peel-off}

Polivinil alkohol ditambah aquadest empat kalinya lalu dipanaskan pada suhu $80^{\circ} \mathrm{C}$ sampai warnanya bening dan homogen. HPMC dikembangkan dengan aquadest panas dibiarkan selama 30 menit hingga mengembang sempurna. Campur keduanya dalam lumpang gerus homogen. kemudian ditambahkan propilenglikol, dan metil paraben yang telah dilarutkan dalam aquadestilata panas, dan HPMC yang telah mengembang dimasukkan secara berturut turut kedalam massa PVA, diaduk hingga homogen. Setelah itu ditambahkan ekstrak etanol bawang dayak sedikit demi sedikit lalu diaduk hingga homogen.

\section{Pengujian Daya Hambat Sterilisasi Alat}

Alat-alat yang digunakan dicuci bersih dengan sabun dan dibilas hingga bersih kemudian dikeringkan. Alat-alat yang telah kering ini dibungkus menggunakan kertas cokelat, alat-alat disterilkan menggunakan oven pada suhu $170^{\circ} \mathrm{C}$ selama $2 \mathrm{jam}$. Untuk alat seperti ose dan pinset disterilkan dengan cara dipijarkan pada api spiritus.

\section{Pembuatan Medium Nutrient Agar}

7 gram NA instant dilarutkan dalam $250 \mathrm{ml}$ aquadest panas steril, lalu diaduk dengan mengunakan batang pengaduk sampai larut, dan disterilkan dalam autoclaf pada suhu $121^{\circ} \mathrm{C}$ selama 15 menit.

\section{Peremajaan Bakteri Uji}

Kultur murni bakteri uji diinokulasikan sebanyak 1 ose pada medium agar miring Nurtient Agar(NA) dalam tabung reaksi dengan cara digoreskan secara aseptik, kemudian diinkubasi selama 24 jam pada suhu $37^{\circ} \mathrm{C}$ (Yusriana, 2014).

\section{Suspensi Kultur Murni Bakteri Uji}

Hasil dari peremajaan bakteri uji disuspensikan dengan cara diambil 1 ose bakteri uji yang telah diremajakan dan dimasukan kedalam tabung reaksi yang telah berisi $10 \mathrm{ml} \mathrm{NaCl}$ fisiologis (Yusriana, 2014). 


\section{Pembuatan Larutan Sampel}

Masker gel peel-off ekstrak bawang dayak (Eleutherine palmifolia) dan ekstrak bawang dayak (Eleutherine palmifolia) dibuat dengan konsentrasi masing-masing 5\%, 7,5\% dan $10 \%$ dibuat dengan cara menimbang masker gel peel-off ekstrak bawang dayak (Eleutherine palmifolia) dan ekstrak bawang dayak (Eleutherine palmifolia), ekstrak bawang dayak ditimbang sebanyak $0,50 \mathrm{~g}, 0,75 \mathrm{~g}, 1 \mathrm{~g}$, kemudian pada masker peel-off dibuat dengan cara menimbang sebanyak 10 gram masing- masing sediaan setelah itu dilarutkan dengan aqua p.i hingga $10 \mathrm{ml}$ serta untuk kontrol positif dilarutkan bersama aqua p.i dengan perbandingan mediklin : aqua p.i (1:1) dan diberi tanda berdasarkan konsentrasi.

\section{Penyiapan Cakram Disc}

Kertas cakram disc dengan diameter 0,6 cm disiapkan kemudian direndam kedalam masingmasing larutan sampel selama 15 menit, dilakukan secara aseptic kemudian diletakkan pada medium yang digunakan.

\section{Pengujian Daya Hambat}

Pengujian daya hambat masker gel peel-off ekstrak bawang dayak (Eleutherine palmifolia) dan ekstrak bawang dayak (Eleutherine palmifolia) dilakukan dengan metode difusi mengunakan kertas cakram. Suspensi bakteri uji dituangkan kedalam cawan petri sebanyak $1 \mathrm{ml}$, kemudian ditambahkan $10 \mathrm{ml}$ medium Na steril yang telah didinginkan sampai suhu $40^{\circ} \mathrm{C}-45^{\circ} \mathrm{C}$. Cawan petri ditutup dan digoyang-goyangkan hingga tercampur homogen,lalu dibiarkan sampai membeku.Selanjutnya, kertas cakram yang telah di rendam dalam sampel pada masing-masing konsentrasi diletakakn pada permukaan medium Nutrient Agar (NA) yang telah berisi bakteri uji kemudian diinkubasi didalam inkubator pada suhu $37^{\circ} \mathrm{C}$ selama $2 \times 24$ jam dengan posisi terbalik (Pratiwi, 2008).

\section{Pengamatan}

Penentuan daya hambat pertumbuhan bakteri uji dilakukan dengan mengukur diameter daerah bening sekitar kertas cakram dan dilakukan identifikasi bakteri Staphylococcus aureus (SA) untuk penelitian. Pengamatan dilakukan setelah diinkubasi didalam inkubator selama 2x24 jam dengan mengunakan alat jangka sorong.

\section{ANALISIS DATA}

Pengumpulan data dilakukan dengan mengukur diameter daerah bening sekitar kertas cakram yang tidak ditumbuhi bakteri menggunakan jangka sorong. Analisis data dibuat dalam bentuk tabulasi (tabel) dan dijelaskan secara deskriptif.

\section{HASIL DAN PEMBAHASAN}

Sampel yang digunakan pada penelitian ini adalah tanaman bawang dayak yang memiliki nama latin Eleutherina palmifolia yang diambil dari Rasau Jaya, Kabupaten Kubu Raya, Provinsi Kalimantan Barat. Pada penelitian ini diperoleh rendemen sebesar 8,07\% ekstrak kental bawang dayak dengan warna coklat kehitaman dan berbau khas bawang dayak. Penelitian ini merupakan uji eksperimental yang bertujuan untuk mengetahui apakah pembentuk film PVA dalam sediaan masker gel peel-off ekstrak bawang dayak (Eleutherine palmifolia) terhadap pertumbuhan bakteri pembentukan jerawat Stapyhlococcus aureus memiliki daya hambat terhadap bakteri Staplylococcusaureus dengan mediklin sebagai kontrol positif dan konsentrasi ekstrak sebesar 5\%, 7,5\%, 10\% sedangkan sediaan masker gel peel-off dengan konsentrasi sebesar 5\%, 7,5\%, 10\% menggunakan metode cakram disk. Metode ini adalah metode yang paling sering digunakan untuk menentukan kepekaan mikroba terhadap berbagai macam obat-obatan, pada metode ini digunakan cakram disk yang berfungsi sebagai tempat menampung mikroba, cakram disk terlebih dahulu direndam dengan larutan uji sesuai konsentrasi yang telah ditetapkan selama 15 menit kemudian diletakkan pada lempeng agar yang telah diberi bakteri uji dengan metode tuang, kemudian diinkubasi pada suhu $37^{\circ} \mathrm{C}$ dalam waktu $2 \times 24$ jam. Hasil pengamatan yang diperoleh berupa ada atau tidaknya daerah daya hambat atau daerah bening yang terbentuk disekeliling cakram disc. 
Hasil pengukuran dari daya hambat esktrak etanol bawang dayak (Eleutherina palmifolia (L.)Merr) terhadap bakteri Staplylococcus aureus setelah diinkubasi selama 2x24 jam terdapat daya hambat disekitar kertas cakram, yang artinya esktrak etanol bawang dayak (Eleutherina palmifolia (L.)Merr) memiliki efek terhadap antibakteri Staplylococcus aureus.

Tabel I. Diameter Daya Hambat Ekstrak Etanol Bawang Dayak Terhadap Bakteri Staplylococcus aureus.

\begin{tabular}{|c|c|c|c|c|c|}
\hline \multirow{2}{*}{ Perlakuan } & \multicolumn{3}{|c|}{ Replikasi } & \multirow{2}{*}{$\begin{array}{l}\text { Jumlah } \\
(\mathrm{mm})\end{array}$} & \multirow{2}{*}{$\begin{array}{l}\text { Rata-rata } \\
\quad(\mathrm{mm})\end{array}$} \\
\hline & I & II & III & & \\
\hline Konsentrasi 5\% & 15,6 & 14,8 & 16,3 & 46,7 & $15,5 \pm 0,75$ \\
\hline Konsentrasi 7,5\% & 19,6 & 14,7 & 17,0 & 51,3 & $17,1 \pm 2,45$ \\
\hline Konsentrasi 10\% & 16,6 & 17,3 & 17,6 & 51,5 & $17,1 \pm 0,51$ \\
\hline \multirow[t]{2}{*}{ Kontrol + } & 30,1 & 32,5 & 35,5 & 98,1 & $32,7 \pm 2,70$ \\
\hline & \multicolumn{2}{|c|}{ Total } & & 247,6 & \\
\hline
\end{tabular}

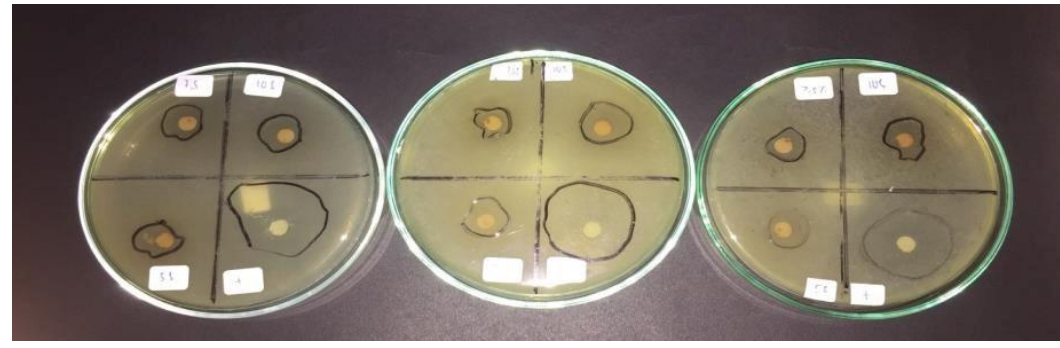

\section{Gambar 1. Gambar Uji Daya Hambat Ekstrak Etanol Bawang Dayak} Terhadap Bakteri Staphylococcusaureus.

PadaTabel I dan gambar 1 menunjukkan total diameter daya hambat esktrak etanol bawang dayak (Eleutherina palmifolia (L.)Merr) terhadap bakteri Staplylococcus aureus pada 3 cawan petri adalah $247,6 \mathrm{~mm}$ dengan rata-rata $82,4 \mathrm{~mm}$.

Dari pengujian diperoleh hasil bahwa diameter daya hambat dari ekstrak bawang dayak (Eleutherinapalmifolia (L.)Merr) terhadap bakteri Staplylococcus aureus pada konsentrasi 5\% ratarata diameter sebesar $15,5 \mathrm{~mm}$, pada konsentrasi $7,5 \%$ rata-rata diameter sebesar $17,1 \mathrm{~mm}$, pada konsentrasi $10 \%$ rata-rata diameter sebesar $17,1 \mathrm{~mm}$ dan diameter rata-rata daya hambat pada kontrol positif adalah sebesar $32,7 \mathrm{~mm}$. Pengujian ini menunjukkan bahwa konsentrasi 5\% ekstrak etanol bawang dayak (Eleutherina palmifolia (L.)Merr) sudah memiliki aktivitas untuk menghambat bakteri Staphylococcus aureus.

Pada penelitian ini bahan - bahan yang digunakan pada pembuatan masker gel peel off ini yaitu ekstrak etanol umbi bawang dayak (Eleutherina palmifolia (L.) Merr) sebagai zat aktif yang berkhasiat sebagai anti bakteri Staplylococcus aureus pada masker gel peel. Polivinil Alkohol (PVA) sebagai pembentuk film, Hipromellose (HPMC) sebagai basis pembentuk gel, Propilenglikol sebagai humektan, dan metil paraben sebagai pengawet. Alasan pengkombinasian PVA dan HPMC karena PVA akan membuat gel mengering secara cepat, lapisan film yang terbentuk sangat kuat dan plastis sehingga memberikan kontak yang baik antara obat dan kulit. Sedangkan HPMC mempunyai kelebihan dapat menghasilkan gel yang jernih, bersifat netral, viskositas stabil dan resisten terhadap pertumbuhan mikroba. Penambahan propilenglikol sebagai humektan agar menjaga kestabilan sediaan gel dengan cara mengabsorbsi lembab dan mengurangi penguapan air, serta metil paraben berfungsi sebagai pengawet sediaan untuk mencegah pertumbuhan mikroorganisme yang dapat masuk secara tidak sengaja. 


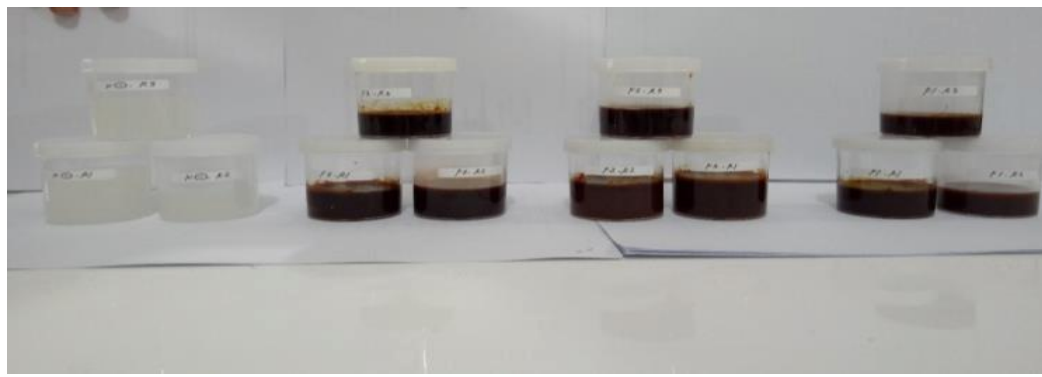

Gambar 2. Sediaan Masker Gel Peel-Off

Umbi bawang dayak (Eleutherine palmifolia) memiliki sifat antibakteri disebabkan karena adanya kandungan alkaloid, flavonoid dan terpenoid yang memiliki efek antibakteri.Pada umumnya absorpsi obat pada sediaan masker gel peel-off (absorpsi perkutan) tidak hanya tergantung pada sifat fisika kimia dari bahan obat saja tetapi juga tergantung pada sifat pembawa dan juga kondisi kulit.Absorpsi perkutan suatu obat dipengaruhi oleh beberapa hal yaitu konsentrasi obat, luas membran tempat sediaan menyebar, derajat kelarutan bahan obat baik dalam minyak maupun air, efek hidrasi kulit, waktu obat menempel pada kulit (Ansel,1989).

Pengujian aktvitas antimikroba masker masker gel peel-off ekstrak bawang dayak (Eleutherine palmifolia) yang telah dilakukan menunjukkan terjadinya penghambatan pertumuhan bakteri Stapyhlococcus aureus yang ditandai dengan adanya zona bening di sekitar cakram. Hasil pengamatan daya hambat masker masker gel peel-off ekstrak bawang dayak (Eleutherine palmifolia) memperlihatkan adanya pengaruh faktor konsentrasi terhadap diameter zona bening yang terbentuk.

Tabel II. Hasil daya hambat dari masker gel peel-off ekstrak bawang dayak (Eleutherine palmifolia) terhadap pertumbuhan bakteri pembentukan jerawat Stapyhlococcus aureus.

\begin{tabular}{|c|c|c|c|c|c|}
\hline \multirow{2}{*}{ Perlakuan } & \multicolumn{3}{|c|}{ Replikasi } & \multirow{2}{*}{ Jumlah (mm) } & \multirow{2}{*}{ Rata-Rata (mm) } \\
\hline & $\mathrm{I}$ & II & III & & \\
\hline Formula 1 & 10,6 & 8,5 & 7,2 & 263 & $8,7 \pm 1,71$ \\
\hline Formula 2 & 12,8 & 9,8 & 14,1 & 36,7 & $12,2 \pm 2,20$ \\
\hline Formula 3 & 16,5 & 13,3 & 16,2 & 46 & $15,3 \pm 1,76$ \\
\hline \multirow[t]{2}{*}{ Kontrol + } & 21,7 & 16,1 & 25,1 & 62,9 & $20,9 \pm 4,54$ \\
\hline & Tot & & & 171,9 & \\
\hline
\end{tabular}

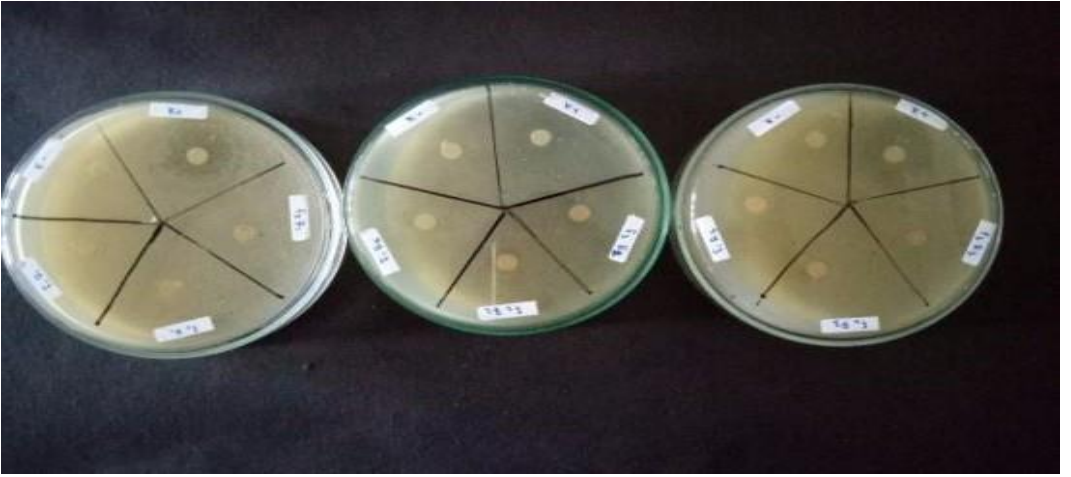

Gambar 3. Gambar Uji Daya Hambat Masker Gel Peel-Off

Berdasarkan Tabel II diatas diameter daya hambat dari masker gel peel-off ekstrak bawang dayak (Eleutherine palmifolia) pada formulasi 1 yang didalamnya terdapat ekstrak bawang dayak (Eleutherine palmifolia) konsetrasi $5 \%$ berdiameter sebesar $8,7 \mathrm{~mm}$, pada konsentrasi $7,5 \%$ didalam formulasi 2 berdiameter sebesar $12,2 \mathrm{~mm}$, dan pada konsentrasi $10 \%$ didalam formulasi 3 
berdiameter sebesar $15,3 \mathrm{~mm}$ dan diameter rata-rata daya hambat pada kontrol positif adalah sebesar 20,9 $\mathrm{mm}$.

Dari hasil pengamatan yang diperoleh dilanjutkan dengan melalui analisis variabel secara sistematika menggunakan uji statistik ANOVA one-way. Hal ini dimaksudkan untuk melihat apakah ada pengaruh dari kedua perlakuan terhadap diameter daya hambat dengan data yang lebih spesifik dan signifikan secara sistematik.

Hasil analisis statistik dengan ANOVA one-way tidak menunjukkan adanya perbedaan yang sangat nyata diantara perlakuan (sig 0,405 > 0,05) sehingga dapat ditarik kesimpulan bahwa pembentuk film PVA tidak berpengaruh pada sediaan masker gel peel-off ekstrak bawang dayak (Eleutherine palmifolia) terhadap aktivitas antibakteri Staphylococcus aureus penyebab jerawat.

\section{KESIMPULAN}

Hasil penelitian ini menunjukkan bahwa pembentuk film PVA tidak berpengaruh pada sediaan masker gel peel-off ekstrak bawang dayak (Eleutherine palmifolia) terhadap aktivitas antibakteri Staphylococcus aureus penyebab jerawat.

\section{DAFTAR PUSTAKA}

Ansel, H. C. 1989. Pengantar Bentuk Sediaan Farmasi . Edisi ke-4. Terjemahan Farida Ibrahim. UI- Press. Jakarta.

Badan POM RI. 2009. Bahan-bahan Kosmetik Sebagai Anti Acne. Naturakos 10 (4):2-3.

Firdaus. 2014. Efektivitas Ekstrak Bawang Dayak (Eleutherina palmifolia (L.) Merr) Dalam Menghambat Pertumbuhan Bakteri Staplylococcus aureus. Skripsi. Program Studi Pendidikan Dokter, Fakultas Kedokteran Dan Ilmu Kesehatan, Universitas Islam Negeri Syarief Hidayatullah. Jakarta.

Kalidass S, Sembian S, Femina W, Febina B, Gilbert R,. 2012. Antagonistic Activity of Eleutherine palmifolia Linn. Asian Pacific Journal of Tropical Disease. Elsevier. India.

Mierza V, Suryanto D, Pandabotan M, Nasution,. 2011. Skrining Fitokimia dan Uji Efek Antibakteri Ekstrak Etanol Bawang Sabrang (Eleutherine palmifolia Merr). Prosiding Seminar Nasional Biologi. USU Press. Medan.

Pratiwi S.T. 2008. Mikrobiologi Farmasi. Erlangga. Yogyakarta.

Rowe, R. C., P. J. Sheskey, dan M. E. Quinn. 2009. Handbook of Pharmaceutical Excipients Sixth Edition. Pharmaceutical Press and the American Pharmacist Association. USA.

Yusriana C.S., Chrisnawan S.B., Trisna D. 2014. Uji Daya Hambat Infusa Daun Nangka (Artocarpuus heterophyllus) Terhadap Pertumbhan Bakteri Staplylococcus aureus. Jurnal Permata Indonesia Vol 5 (2) : 1-7. Politeknik Kesehatan Permata Indonesia. Yogyakarta. 